\title{
PENGEMBANGAN PERANGKAT PEMBELAJARAN UNTUK MEMPERCEPAT PENYELESAIAN SKRIPSI MAHASISWA
}

\author{
Heri Suwignyo dan Muakibatul Hasanah \\ Fakultas Sastra Universitas Negeri Malang \\ e-mail: heri.suwignyo.fs@um.co.id
}

\begin{abstract}
Abstrak
Penelitian ini bertujuan menghasilkan perangkat pembelajaran untuk mempercepat penulisan skripsi mahasiswa Jurusan Sastra Indonesia. Metode penelitian dan pengembangan yang digunakan adalah model Borg dan Gall yang telah dimodifikasi. Hasilnya pada tahap prapengembangan ditemukan: (a) penyebab kecenderungan lama studi dan kategori skripsi mahasiswa, dan (b) kebutuhan perangkat pembelajaran yang relevan. Pada tahap pengembangan dihasilkan bahan ajar dasar-dasar penelitian dan sarana monitoring proses penulisan dan produk penulisan skripsi. Pada tahap pascapengembangan dihasilkan bahan ajar penelitian, sarana monitoring proses dan produk penulisan skripsi, dan panduan penilaian ujian/sidang skripsi yang telah teruji kelayakannya.
\end{abstract}

Kata kunci: perangkat pembelajaran, bahan ajar, sarana monitoring proses penulisan, produk penulisan

\section{DEVELOPING A LEARNING PACKAGE TO ACCELERATE THE COMPLETION OF STUDENTS' UNDERGRADUATE THESES}

\begin{abstract}
This study aims to produce a learning package to accelerate undergraduate thesis writing among students of the Department of Indonesian Literature. The research and development method was Borg and Gall's model that was modified. The results in the pre-development stage were: (a) causes of the study length tendency and students' thesis categories, and (b) the relevant learning package. In the development stage, learning materials for research foundations and an instrument to monitor the thesis writing process and product were produced. In the post-development stage, research learning materials, an instrument to monitor the thesis writing process and product, and a guide for the assessment of the thesis examination/defence were produced after the appropriateness was tested.
\end{abstract}

Keywords: learning package, learning materials, instrument to monitor the writing process, writing product

\section{PENDAHULUAN}

Sikap ilmiah selayaknya dimiliki oleh setiap mahasiswa. Sikap ilmiah di antaranya ditunjukkan oleh kepekaan dan kemampuan mahasiswa dalam merespon lingkungannya melalui penelitian yang diwujudkan dalam bentuk skripsi atau karya kreatif. Skripsi merupakan tugas akhir mahasiswa yang idealnya diselesaikan tepat waktu. Namun demikian, tidak semua mahasiswa dapat menyelesaikan skripsi tepat waktu. Berbagai kendala telah dihadapi, baik internal maupun eksternal. Kondisi ini tentu akan berpengaruh ter- 
hadap realisasi visi institusi yang ingin menjadikan lembaga sebagai wadah pendidikan tinggi yang unggul dalam mengembangkan ilmu sesuai dengan bidangnya dan misi perguruan tinggi,yakni meningkatkan mutu, relevansi, dan daya saing melalui Tridharma Perguruan Tinggi.

Peningkatan mutu, relevansi, dan daya saing hanya dapat diperoleh jika para mahasiswa mampu menyongsong berbagai inovasi perkembangan ipteks. Ditbelmawa Dikti (2014) mengungkapkan bahwa umumnya inovasi terjadi didorong oleh kuatnya kebutuhan perubahan/peningkatan secara kualitatif dan dukungan akumulasi hasil riset, ilmu pengetahuan dan teknologi serta seni yang tertata secara baik. Agar mahasiswa memiliki andil dan kemampuan untuk berperan dalam perkembangan ipteks, mereka perlu dibekali kemampuan untuk merespon lingkungannya dan melakukan eksplorasi dalam kegiatan penelitian. Hal itu sejalan dengan butir kedua KKNI untuk sarjana/diploma IV bahwa mereka dituntut menguasai konsep teoretis bidang pengetahuan tertentu secara umum dan konsep teoretis khusus pada bidang pengetahuan tersebut secara mendalam serta mampu memformulasikan penyelesaian masalah prosedural (Mendikbud, 2013; Ditbelmawa Dikti, 2014).

Learning outcome demikian itu akan dapat dicapai di antaranya jika mereka dibekali pengetahuan dan keterampilan yang memadai serta metodologi ilmiah yang matang dalam meneliti bidang pengetahuan yang secara khusus ditekuninya. Dengan demikian, mereka dapat melakukan penelitian dengan benar secara teoretis dan metodologis dan akhirnya mereka dapat menyelesaikan studinya tepat waktu. Penyelesaian studi tepat waktu merupakan harapan setiap mahasiswa dan perguruan tinggi. Namun demikian, harapan ini tidak selalu terwujud karena berbagai kendala. Melalui penelitian ini, diharapkan hasilnya akan dapat mem- bantu mahasiswa agar mereka dapat menyelesaikan studinya tepat waktu. Untuk itu, diperlukan pengembangan perangkat pembelajaran yang diduga dapat mengatasi persoalan dimaksud.

Persoalan penyelesaian studi tepat waktu merupakan persoalan besar bagi setiap perguruan tinggi. Besarnya jumlah mahasiswa setiap perguruan tinggi haruslah seimbang dengan besarnya kelulusan mahasiswa setiap tahunnya. Perguruan tinggi dinyatakan unggul di antaranya dapat dilihat dari kuantitas dan kualitas lulusannya.

Mengacu pada Indonesian Qualification Framework (Mendikbud, 2013; Ditbelmawa Dikti, 2014) secara tersirat visi "keunggulan" menjadi target setiap lembaga pendidikan. Statuta Universitas Negeri Malang 2012 dan Rencana Strategis Bisnis Universitas Negeri Malang (Renstrabis) 2014-2019 mencantumkan target keunggulan dalam visi, misi, dan tujuan. Visi UM adalah menjadi perguruan tinggi unggul dan menjadi rujukan dalam penyelenggaraan tridharma perguruan tinggi. Dalam salah satu tujuan dinyatakan bahwa UM menghasilkan karya ilmiah dan karya kreatif yang unggul dan menjadi rujukan dalam ilmu pendidikan, ilmu pengetahuan, teknologi, ilmu sosial budaya, seni, dan/atau olah raga.

Yang dimaksud dengan pendidikan berwawasan keunggulan adalah kemampuan dunia pendidikan dalam mengaktualisasi secara maksimal dan berkelanjutan segenap potensi yang ada untuk meraih prestasi terbaik dari setiap aktivitas belajar di berbagai jenjang, jenis, dan jalur pendidikan. Aktualisasi tersebut menyangkut kemampuan kognitif, afektif, dan psikomotorik.

Kemampuan kognitif merujuk pada kemampuan berpikir logis dan kreatif. Kemampuan berpikir logis antara lain ditandai dengan kemampuan berpikir sistematis, proporsional, probabilistik, dan korelasional (Anderson, 2001). Ke- 
mamapuan berpikir kreatif antara lain ditandai dengan kelancaran berpikir (fluency), keluwesan berpikir (flexible), keorisinalan berpikir (orisinality), dan kerincian berpikir (elaborative). Kemampuan afektif merupakan kemampuan seseorang mengembangkan perasaan dan emosinya secara lebih profesional dan bertanggung jawab ke arah tercapainya keseimbangan antara rasio, indera, persepsi imajinasi, dan karsa. Kemampuan afektif dimaksudkan untuk mempertinggi keteguhan seseorang dalam menunaikan tugas dan tanggung jawab.Bagi siswa, komitmen ini dapat diukur melalui penyelesaian tugastugas dalam kegiatan belajar yang berorientasi pada pencapaian prestasi maksimal sesuai dengan kemampuan psikologis yang dimilikinya. Adapun dimensi psikomotorik ditandai dengan keterampilan dan daya tahan fisik yang prima dalam penyelesaian tugas-tugas akademik yang merupakan wujud dari gabungan antara sejumlah proses psikomotorik dan bekerja secara maksimal unsur-unsur fisik yang relevan untuk menunaikan tugas.

Bertolak dari uraian visi demikian itu, usaha mengembangkan perangkat pembelajaran untuk mempercepat penyelesaian studi mahasiswa dipandang sebagai salah satu langkah awal yang diduga dapat mendukung terwujudnya visi "keunggulan". Pengembangan perangkat pembelajaran tersebut memiliki fungsi ganda dilihat dari manfaatnya. Hasil penelitian ini akan bermanfaat bagi (1) lembaga (Universitas Negeri Malang) dan lembaga lain (PT lain) sebagai sarana yang secara langsung dapat membantu mempercepat penyelesaian skripsi mahasiswa, dan (2) negara sebagai sarana untuk memenuhi tuntutan peningkatan kualitas pendidikan di Indonesia dan realisasi pembangunan manusia dan daya saing bangsa.

Peningkatan mutu, relevansi, dan daya saing bangsa hanya dapat diperoleh jika para mahasiswa memiliki ketekunan dan keuletan serta mampu menyongsong berbagai inovasi perkembngan ipteks dan sosial-budaya. Untuk menyongsong perkembangan tersebut, di antaranya dilakukan dengan cara meneliti. Namun demikian, kenyataan menunjukkan bahwa mahasiswa sering mengalami kesulitan dalam menulis karya ilmiah, termasuk skripsi. Soehardjo (2005) menyatakan bahwa sebagian besar mahasiswa mengalami kesulitan terkait dengan kesalahan dalam: (1) memahami audience atau pembaca tulisannya, (2) menyusun struktur pelaporan, (3) cara mengutip pendapat orang lain sehingga berkesan menjiplak (plagiat), (4) menuliskan bagian simpulan, (5) penggunaan Bahasa Indonesia dengan baik dan benar, (6) kekurangtepatanpenulisan daftar pustaka, (7) ketidak konsistenan dalam penampilan format (font yang berubah-ubah, margin yang berubahubah), (8) ringkasnya sajian isi (karena dibuat dengan menggunakan point-form sebagaimana materi presentasi), dan (9) ketidakseimbangan sajian isi dan pengantar (isi cenderung ringkas dibandingkan dengan pengantar).

Memperkuat temuan Soehardjo, Setiadi (2016) menemukan kualitas kemampuan menulis akademik (baca menulis karya ilmiah) para guru berikut ini. Kompetensi para guru lulus sertifikasi (sebanyak 126 guru) menunjukkan bahwa secara keseluruhan, skor rata-rata tulisan akademik yang dicapai mereka adalah 57,2 dari skor total 100. Merujuk kepada skalapenilaian tulisan akademik, skor rata-rata ini berkategori "cukup baik."

Hal menarik dari pengamatan Soehardjo (2005) adalah mahasiswa seringkali tidak mau melaporkan kegagalan atau kesalahan yang telah dilakukannya. Padahal, kegagalan ini perlu dicatat agar hal itu tidak dilakukan oleh orang lain (yang akan meneruskan penelitian tersebut). Kegagalan bukan sebuah 'aib.'Seorang peneliti pasti mengalami kegagalan. Karena itu, Soehardjo (2005) menyarankan perlu-nya melaporkan kegagalan tersebut 
dan menganalisis atau menduga mengapa hal tersebut bisa terjadi.

Kesalahan-kesalahan penulisan skripsi sebagaimana digambarkan Soehardjo (2005) di atas perlu diantisipasi agar tidak terjadi pada mahasiswa lain.

Menurut Ardianto (2015) mahasiswa terbukti mampu menggunakan struktur argumen di dalam karya tulis ilmiah secara bervariasi. Struktur argumen dimaksud baik yang sederhana maupun yang kompleks, baik struktur argumen deduktif maupun struktur argumen induktif.

Penelitian dan pengembangan ini bertujuan menghasilkan (1) bahan ajar matakuliah penelitian, dan (2) sarana monitoring (sarmon) proses penulisan skripsi dan produk penulisan skripsi. Pengembangan perangkatpembelajaran tersebut diduga dapat membantu mahasiswa dalam menyelesaikan skripsinya sehingga mereka dapat menyelesaikan studinya tepat waktu. Dengan urgensi seperti itu, penelitian ini layak dilakukan.

\section{METODE}

Penelitian ini menggunakan metode penelitian dan pengembangan Borg dan Gall (2003) yang telah dimodifikasi. Penelitian bertujuanmenghasilkan perangkat pembelajaran untuk mempercepat penyelesaian skripsi mahasiswa yang berupa: (1) buku ajar dasar penelitian, (2) sarana monitoring proses dan produk penulisan, dan (3) sarana penilaian ujian/sidang skripsi.

Secara prosedural langkah pengembangan dilakukan melalui tahap pendahuluan, pengembangan produk, serta uji kelayakan dan uji keefektifan produk. Pada langkah pendahuluan dilakukantiga kegiatan, yakni (i) pengajian teori: karya ilmiah dan penulisannya, media pembelajaran (sarana monitoring), dan evaluasi karya tulis; (ii) survei terhadap: lama studi mahasiswa, kategori skripsi, silabus, dan tanggapan pembimbing skripsi; dan (iii) pembuatan rancangan buku ajar.
Pada langkah pengembangan produk dilakukan 2 kegiatan, yakni (i) pengembangan prototipe bahan ajar dan pengembangan prototipe sarana monitoring proses dan hasil penulisan serta panduan penilaian skripsi. Pada langkah ferifikasi produk dilakukan dua kegiatan, yakni (i) uji pakardan (ii) uji kelas/lapangan. Uji produk oleh pakar (pengampu matakuliah penelitian dan pembimbing skripsi), uji kelayakan sarana monitoring proses penulisan dan produk penulisan skripsi oleh pembimbing skripsi; serta uji keefektifan bahan ajar dan sarmon oleh mahasiswa penempuh matakuliah skripsi.

Sesuai dengan prosedur penelitian dan pengembangan, data prapengembangan dalam penelitian ini berupa: (1) hasil pengajian teori dan (2) hasil survai tentang lama studi mahasiswa, kecenderungan kategori skripsi mahasiswa, deskripsi dan silabus matakuliah, serta tanggapan pembimbing skripsi. Data (1) bersumber dari buku teori tentang penulisan skripsi, jenis-jenis penelitian, sarana monitoring sebagai media pembelajaran, dan penilaian pembelajaran dan data (2) bersumber dari dokumen lama studi mahasiswa, skripsi mahasiswa, katalog JPBSI UM, dan pembimbing skripsi.

Data yang sudah terkumpul pada langkah pendahuluan dianalisis dan hasilnya dijadikan dasar pengembangan bahan ajar dan penyusunan sarana monitoring proses penulisan dan produk penulisan skripsi. Data bahan ajar penelitian mencakup data kelayakan bahan ajar yang mencakup aspek (a) keterbacaan isi/materi, (b) keruntutan penyajian, dan (c) kemenarikan tampilan bahan ajar oleh pengampu matakuliah penelitian. Data kelayakan sarana monitoring memfokus pada (a) proses penulisan skripsi, (b) penilaian kelayakan naskah skripsi, dan (c) penilaian ujian/sidang skripsi oleh pembimbing.

Kedua kelompok data tersebut dikumpulkan melalui panduan penilaian kela- 
yakan bahan ajar dan panduan monitoring proses penulisan skripsi dan panduan penilaian kelayakan naskah skripsi serta panduan penilaian ujian/sidang skripsi. Untuk menjamin keabsahan data dilakukan triangulasi peneliti dengan cara pengambilan dan penganalisisan data yang sama oleh peneliti berbeda (anggota tim peneliti berbeda).

Analisis data dilakukan secara kualitatif dengan merujuk pandangan Miles dan Huberman (1992) melalui prosedur: (1) sajian data, (2) reduksi data, (3) verifikasi, dan (4) penarikan simpulan.

\section{HASIL DAN PEMBAHASAN}

Kecenderungan Lama Studi Mahasiswa

Kecenderungan lama studi mahasiswa 3 tahun terakhir ditemukan sebagai berikut. Pada tahun akademik 2011-2012 semester gasal, rata-rata lama semester 10 , IP rata-rata 3.32, semester genap rata-rata lama semester 10, IP rata-rata 3,44, semester pendek rata-rata lama semester 10,23, IP rata-rata 3,28. Pada tahun akademik 2012-2013 semester gasal, rata-rata lama semester 10,10; IP rata-rata 3.38, semester genap rata-rata lama semester 9 , IP ratarata 3,43, semester pendek rata-rata lama semester 10,66, IP rata-rata 3,45. Pada tahun akademik 2013-2014 semester gasal, rata-rata lama sesmeter 10,15; IP rata-rata 3.42 , semester genap rata-rata lama semester 10,10; IP rata-rata 3,45, semester pendek rata-rata lama semester 10,66 , IP rata-rata 3,38 .

Temuan demikian dimaknai bahwa pertama, mahasiswa Program Studi Bahasa dan Sastra Indonesia (1) angkatan 2011/2011 rata-rata kelulusan mereka dalam rentang waktu 10,07 semester; (2) angkatan 2012/2013 rata-rata kelulusan mereka dalam rentang waktu 9,92 semester; dan (3) angkatan 2013/2014 rata-rata kelulusan mereka dalam rentang waktu 10,33 semester. Kedua, indeks prestasi (1) angkatan 2011/2012 rata-rata 3,34; (2) angkatan 2012/2013 rata-rata 3,38; dan (3) angkatan 2013/2014 rata-rata 3,64 (FS UM,
2014). Dengan melihat rata-rata tersebut ditafsirkan bahwa (1) dilihat dari rentang waktu kuliahnya, ada penurunan jumlah semester, namun terjadi peningkatan lagi di tahun terakhir; namun (2) IP mereka semakin meningkat, semakin baik.

Terkait dengan pengembangan perangkat pembelajaran yang dikembangkan dalam penelitian ini, ada 2 pertimbangan yang diperhitungkan: (1) perangkat yang dikembangkan dirancang dapat mempersingkat penyelesaian kuliah/skripsi mahasiswa secara ajek, tidak fluktuatif dan (2) IP mahasiswa ditargetkan semakin meningkat. Agar target tersebut bisa diraih, lima haltepat yang dilakukan adalah (1) mengembangkan bahan ajar penelitian yang disertai dengan perlatihanperlatihan yang rutin, mulai dari pemahaman teori sampai dengan aplikasinya; (2) mengembangkan bahan ajar perkuliahan penelitian yang memungkinkan mahasiswa dapat berlatih merancang dan mempraktikkan penelitian lingkup terbatas secara merata; (3) membuat sarana monitoring yang memungkinkan dapat memantau perkembangan kerja mahasiswa dalam membuat skripsi secara individual, mulai dari persiapan sampai selesai; (4) membuat sarana monitoring yang memungkinkan dapat memantau sikap mahasiswa dalam membuat skripsi dan saat bimbingan dengan pembimbing secara individual; dan (5) membuat instrumen penilaian ujian skripsi yang dapat mengukur aspek sikap, wujud laporan/ skripsi, dan performansi ujian.

Lima hal tersebut sejalan dengan hasil penelitian (Hartato, 2016) yang menyatakankan bahwa kualitas bimbingan (kelengkapan bahan ajar dan sarana monitoring) adalah salah satu faktor di antara 4 faktor yang lain yang memengaruhi penyelesaian skripsi mahasiswa. Empat faktor dimaksud adalah (1) motivasi lulus tepat waktu, (2) kompetensi menulis karya tulis ilmiah, (3) ketersediaan sumber belajar, dan (4) pengaruh teman sebaya. 


\section{Kategori Skripsi Mahasiswa}

Kategori skripsi mahasiswa dieksplorasi 4 tahun terakhir, mulai masa yudisium semester gasal 2011-2012 sampai dengan yudisium semester pendek 2013-2014. Ditemukan bahwa skripsi yang dihasilkan mahasiswa dikategorikan dalam jenis penelitian lapangan atau field research, penelitian tindakan kelas atau clasroom action research, serta penelitian dan pengembangan atau research and development.

Pertama, kategori penelitian lapangan dipilah atas penelitian kuantitatif dan kualitatif. Penelitian kuantitatif dipilah atas: penelitian deskriptif, eksperimentalnoneksperimental, dan penelitian korelasional. Penelitian kualitatif dipilah atas: penelitian deskriptif, interaktif-noninteraktif, dan studi kasus.

Kategori ketiga dan keempat adalah penelitian tindakan kelas dan penelitian pengembangan. Sasaran penelitian sebagian besar di sekolah menengah pertama dan menengah atas (SMP-SMA) dan sebagian kecil di jenjang sekolah dasar bahkan di sekolah anak berkebutuhan khusus, misalnya di Sekolah Autis Universitas Negeri Malang.

Data tentang jenis penelitian yang sering dikerjakan mahasiswa dijelaskan berikut ini. Jumlah responden 6 pembimbing skripsi. Responden yang menyatakan bahwa penelitian yang sering dikerjakan mahasiswa berkategori (1) penelitian kuantitatif pembelajaran bahasa dan sastra Indonesia berjumlah 3 orang; (2) penelitian kualitatif tentang bahasa berjumlah 4 orang; (3) kualitatif tentang sastra berjumlah 4 orang; (4) penelitian kualitatif tentang pembelajaran bahasa dan sastra Indonesia berjumlah 4 orang; (5) penelitian tindakan kelas berjumlah 3 orang; dan

(6) penelitian pengembangan berjumlah 3 orang.

Penelitian yang jarang dikerjakan mahasiswa berkategori (1) penelitian kuantitatif tentang bahasa berjumlah 4 orang; (2) penelitian kuantitatif tentang sastra ber- jumlah 4 orang; (3) penelitian kuantitatif tentang pembelajaran bahasa dan sastra Indonesia berjumlah 2 orang; (4) penelitian kualitatif tentang bahasa 1 orang; (5) penelitian kualitatif tentang sastra 1 orang; dan (6) penelitian pengembangan 1 orang.

Kedua paparan data tersebut ditafsirkan berikut ini. Pertama, penelitian yang paling banyak dikerjakan oleh mahasiswa adalah jenis penelitian kualitatif tentang bahasa, sastra, dan pembelajaran bahasa dan sastra. Urutan berikutnya adalah penelitian kuantitatif pembelajaran bahasa dan sastra. Kedua, penelitian yang paling jarang dikerjakan mahasiswa adalah jenis penelitian kuantitatif tentang bahasa dan sastra. Urutan berikutnya secara berturutturut adalah penelitian kuantitatif pembelajaran bahasa dan sastra Indonesia, penelitian kualitatif tentang bahasa, penelitian kualitatif tentang sastra dan penelitian pengembangan.

Berdasarkan hasil interpretasi tersebut, tiga hal yang perlu dipertimbangkan terkait dengan pengembangan perangkat pembelajaran adalah: (1) memberikan perlatihan yang cukup terkait dengan penelitian kuantitatif tentang bahasa dan sastra karena penelitian ini jarang dilakukan oleh mahasiswa; (2) berusaha memberikan penjelasan yang terperinci dan mudah dipahami oleh mahasiswa terkait dengan penyajian materi penelitian kuantitatif bahasa dan sastra; (3) memberikan contoh yang cukup terkait dengan penelitian kuantitatif bahasa dan sastra Indonesia. Dengan cara demikian, matakuliah penelitian akan diminati oleh mahasiswa.

\section{Silabus Perkuliahan Penelitian}

Berdasarkan deskripsi dan silabus yang telah ada (FS UM, 2011) dikembangkan deskripsi dan silabus matakuliah dasar-dasar penelitian. Prototipe silabus dimaksud terdiri atas (1) identitas matakuliah yang berisi: nama matakuliah, sandi, semester, sks/js, (2) deskripsi mata- 
kuliah berisi : topik-topik yang diberikan, (3) tujuan perkuliahan berisi: kompetensi yang akan dimiliki mahasiswa, (4) topik dan subtopik perkuliahan mengacu pada isi deskripsi matakuliah, (5) kegiatan perkuliahan, (6) evaluasi berisi: evalusi proses dan hasil; (7) sumber rujukan, (8) jadwal kegiatan dan tagihan perkuliahan yang berisi: agenda pertemuan tiap minggu, dan tagihan hasil perkulihan setiap pertemuan.

Berdasarkan hasil identifikasi data silabus yang digunakan dosen sebagai panduan mengajar matakuliah dasardasar penelitian (FS, UM,2011) ada enam hal yang perlu dipertimbangkan. Pertama, dilihat dari deskripsi isinya, matakuliah Dasar-Dasar Penelitian hanya menekankan keterampilan menerapkan paradigma, pendekatan, metode, dan teknik dalam penelitian; tidak tampak adanya penanaman pengetahuan. Kedua, tujuan perkuliahan dengan deskripsi isi tidak sesuai karena tujuannya selain menekankan aspek keterampilan juga menanamkan pengetahuan dan kemampuan menilai laporan penelitian. Ketiga, topik perkuliahan yang disajikan juga tidak sesuai dengan tujuan perkuliahan karena dilihat dari cakupan materinya tidak hanya menanamkan pengetahuan dan keterampilan merancang penelitian, tetapi sampai pada penulisan laporan penelitian. Tetapi penilaian laporan penelitian tidak ada. Keempat, kegiatan perkuliahan, diawali dengan mendengarkan penjelasan dosen, mengerjakan tugas atau berdiskusi, diikuti penelaahan referensi. Setiap kegiatan perkuliahan untuk mencapai tujuan tertentu diikuti dengan sajian sumber bahan yang sudah ditunjukkan halamannya. Kelima, evaluasi diarahkan pada evaluasi proses dan hasil yang diikuti pembobotan nilai. Evaluasi hasil berupa tes tengah dan akhir semester dan tugas menyusun rencana penelitian. Evaluasi ini pun tidak sesuai dengan tujuan perkuliahan. Keenam, bagian akhir silabus disertai dengan ada- nya daftar sumber bacaan yang bisa dibaca mahasiswa. Daftar bacaan ini cukup memadai (delapan sumber bacaan yang isinya cukup sesuai dengan topik-topik perkuliahan).

Dengan mempertimbangkan enam hasil interpretasi tersebut dikemukakan lima hal terkait dengan pengembangan perangkat perkuliahan yang dikembangkan, khususnya dalam mengembangkan silabus dan kaitannya dengan bahan ajar perkuliahan dasar-dasar penelitian. Bahan ajar yang dikembangkan (1) diawali dengan pengembangan silabus; (2) silabus yang dikembangkan memperhitungkan penanaman aspek pengetahuan dan keterampilan dalam merancang penelitian serta hal-hal teknis terkait dengan format dan tata tulisnya; (3) silabus juga memperhitungkan kesesuaian antara tujuan dengan topik, kegiatan perkuliahan, dan evaluasinya; (4) pada kegiatan perkuliahan perlu menyisihkan waktu untuk tes tengah dan akhir semester; (5) aspek penilaian mengukur sikap dan proses, hasil tes, dan tugas akhir berupa produk rancangan penelitian yang memungkinkan ditindaklanjuti untuk penyusunan skripsi.

Oleh sebab itu,deskripsi dan silabus dasar-dasar penelitian yang disiapkan adalah berikut ini. Deskripsimatakuliah ini menyajikan topik (1) jenis atau ragam penelitian pembelajaran bahasa dan sastra Indonesia (2) metode penelitian pembelajaran bahasa dan sastra Indonesia (PBSI), (3) prosedur penelitian pembelajaran bahasa dan sastra Indonesia, dan (4) penggunan bahasa, tatatulis dan format penulisan usulan atau laporan penelitian pembelajaran bahasa dan sastra Indonesia.

Keempat topik tersebut berfungsi sebagai dasar melakukan penelitian pembelajaran bahasa dan sastra Indonesia di semester berikutnya. Tujuan: dengan mengikuti rangkaian kegiatan belajar dan berlatih, mahasiswa memiliki wawasan konseptual, prosedural, dan prinsipial 
tentang (1) berbagai jenis penelitian pembelajaran bahasa dan sastra Indonesia berdasarkan perspektif tertentu, (2) rangkaian metode penelitian pembelajaran bahasa dan sastra Indonesia, (3) rangkaian prosedur penelitian pembelajaran bahasa dan sastra Indonesia, serta (4) kaidah penggunaan Bahasa Indonesia Keilmuan (BIK), pemilihan tatatulis dan format penulisan usulan/laporan penelitian pembelajaran bahasa dan sastra Indonesia.

Topik/Subtopik: (1) jenis penelitian PBSI: penelitian dasar dan terapan, penelitian kuantitatif eksperimental dan noneksperimental; penelitian kualitatif interaktif dan noninteraktif, penelitian tindakan, penelitian pengembangan, (2) Metode Penelitian PBSI: eksplorasi sumber masalah, perumusan masalah, perumusan teori dan kerangka teori, perumusan asumsi dan hipotesis, pemaparan data dan pembahasan hasil penelitian, pemaparan temuan dan penyimpulan hasil penelitian, (3) Prosedur Penelitian PBSI kegiatan tahap: persiapan penelitian, pengumpulan data, pengolahan data kualitatifkuantitatif, validasi hasil analisis data kualitatif-kuantitatif, penyusunan laporan penelitian; (4) Penggunaan Bahasa Indonesia Keilmuan (BIK), Tatatulis, dan FormatPenulisan Laporan Penelitian PBSI.

Kegiatan perkuliahan:informasi, curah pendapat, telaah kasus, diskusi, tugas, dan presentasi.Evaluasi:rata-rata tugas $(20 \%)$, responsi dan partisipasi (20\%), UTS $(20 \%)$, dan UAS (40\%). Sumber rujukan: wajib dan anjuran. Jadwal pertemuan, kegiatan perkuliahan, dan tagihan. Deskripsi dan silabus inilah yang menjadi dasar pengembangan prototipe buku ajar Dasar-Dasar Penelitian Pembelajaran Bahasa dan Sastra Indonesia.

\section{Tanggapan Dosen Pembimbing Skripsi}

Ditemukan tanggapan dosen pembimbing skripsi berikut ini. Bahwa (1) kesulitan yang terjadi pada mahasiswa saat penulisan skripsi berupa mengembangkan rumusan masalah dari topik yang dipilih, mengembangkan rancangan metode penelitian, mengaplikasikan rancangan yang dibuat dalam menganalisis data, menentukan landasan teori, menentukan hasil analisis data, menginterpretasikan hasil, memolakan hasil; (2) setiap tahunnya, mahasiswa yang menyelesaikan kuliah 5-10 mahasiswa, 10 mahasiswa lebih, dan mereka selesai dalam waktu 1 atau dua semester; (3) kesulitan mahasiswa saat ujian skripsi adalah mempertahankan temuan hasil penelitiansesuai dengan prosedur penelitian.

Tanggapan atau saran-saran yang diberikan oleh dosen pembimbing menyangkut (i) masukan perbaikan topik terpilih, (ii) memberikan tugas banyak membaca referensi, (iii) memberikan tugas banyak membaca hasil penelitian terdahulu/sebelumnya, (iv) perlunyapengolahan data kuantitatif dengan mekanisme statistik, (v) perlu penguasaan program SPSS, (vi) perlunya kesesuaian bidang yang ditekuni mahasiswa dengan judul yang disetujui, (vi) perlunya kesesuaian keahlian pembimbing dengan penugasan pembimbingan, (vii) perlunya standar isi matakuliah skripsi antarjurusan atau antarfakultas, (viii) perlu dipertimbangkan pengembangan pedoman penulisan skripsi karya kreatif, (ix) perlunya dipertimbangkan implementasi uji kelayakan skripsi, $(\mathrm{x})$ perlunya penambahan materi penulisan artikel hasil skripsi, (xi) perlunya standar kompetensi bagi dosen matakuliah metodologi penelitian, (xii) perlunya standar proses pembimbingan, (xiii) perlunya standar kualifikasi penulisan skripsi, dan ujian skripsi, (xiv) perlunya jurusan melakukan penyegaran materi perkuliahan penelitian untuk semua dosen, dan (xv) perlunya jurusan memberikan insentif bagi lulusan terbaik dan skripsi terbaik.

Berdasarkan hasil telaah isian angket pada beberapa dosen pembimbing skripsi diperoleh informasi berkaitan dengan (1) 
kesulitan mahasiswa dalam menyusun skripsi, (2) jumlah mahasiswa yang selesai dalam setahun dan jumlah semester selesainya, (3) kesulitan mahasiswa dalam ujian skripsi, dan (3) saran yang diberikan oleh pembimbing skripsi.

Berdasarkan hasil identifikasi data dikemukakan tujuhinterpretasi berikut ini.Pertama,mahasiswa mengalami kesulitan dalam mengaplikasikan teori, mulai dari merumuskan masalah sampai pada menganalisis data, menentukan hasil, menginterpretasikan hasil, dan memolakan hasil penelitian.Tidak ada kesulitan pemahaman teori bagi mahasiswa. Kedua, Sebagian besar dosen menyatakan bahwa mereka dapat menuntaskan pembimbingan skripsi dan perkuliahan mahasiswa dengan jumlah lebih dari 5 mahasiswa, bahkan lebih dari 10 mahasiswa. Ketiga, umumnya penulisan skripsi selesai dalam 2 semester. Keempat, semua dosen menyatakan bahwa kesulitan mahasiswa dalam ujian skripsi berupa mempertahankan temuan/ hasil penelitian sesuai dengan prosedur penelitian terpilih. Kelima saran-saran dosen yang diberikan untuk perbaikan perkuliahan penelitian dan pelaksaan penulisan serta ujian skripsi cukup memberikan inspirasi terkait dengan pengembangan bahan ajar, monitoring pelaksanaan penulisan skripsi, dan ujian skripsi. Bahkan, saran-saran yang diberikan sampai pada perubahan pengelolaan lembaga terkait dengan hal itu.

Dengan memerhatikan lima interpretasi tersebut, ada empat pertimbangan terkait dengan perangkat pembelajaran yang dikembangkan. Pertama, bahan ajar yang dikembangkan mempertimbangkan kesulitan yang dihadapi mahasiswa, terutama dalam mengaplikasikan teori dengan cara memberikan perlatihanperlatihan praktis penerapan teori.

Kedua, berusaha mengembangkan bahan yang memungkinkan dapat menolong mahasiswa menulis skripsi, misalnya memberikan teori tidak terlalu banyak, tetapi dengan memperbanyak perlatihan agar mereka terbantu dalam menyelesaikan skripsinya.

Ketiga, bahan ajar yang dikembangkan mempertimbangkan penanaman kemampuan berpikir logis agar dapat membantu mahasiswa saat ujian skripsi karena umumnya mereka mengalami kesulitan mempertahankan kebenaran tulisan mereka. Keempat, saran-saran dari dosen pengampu dipertimbangkan dalam pengembangan perangkat pembelajaran ini terutama pengembangan bahan ajar dan sarana monitoring penulisan skripsi: sejak penyusunan proposal sampai dengan presentasi ujian laporan hasil penelitian (skripsi).

\section{Prototipe Bahan Ajar Perkuliahan Dasar- Dasar Penelitian}

Prototipe bahan ajar matakuliah penelitian diberi judul Dasar-Dasar Penelitian Pembelajaran Bahasa dan Sastra Indonesia. Sistematika buku ajar dimaksud terdiri atas bagian awal buku berisi: (1) sampul depan, pengantar, daftar isi, (2) bagian inti buku berisi: pendahuluan, jenis penelitian pembelajaran bahasa dan sastra, metode penelitian pembelajaran bahasa dan sastra, prosedur penelitian pembelajaran bahasa dan sastra, serta bahasa, tatatulis, dan format laporan penelitian, (3) bagian akhir buku terdiri atas: daftar rujukan, glosarium, indeks, dan sampul belakang.

Prototipe bahan ajar yang dikembangkan mencakupempat hal berikut: (1) struktur fisik, (2) isi materi, (3) penyajian materi, dan (4) perlatihan. Struktur fisikbuku ini berisi (1) bagian awal buku: sampul, kata pengantar, daftar isi, (2) bagian inti buku: bahasan topik yang disajikan dalam bab-bab tertentu, dalam setiap bab disajikan tujuan, kegiatan belajar beserta paparan materi, dan perlatihan; serta (3) bagian akhir buku: daftar rujukan, glosarium, indeks, dan sampul belakang. 
Isi materi: dalam buku ini disajikan topik-topik bahasan yang secara garis besar berisi (1) pendahuluan: latar belakang, tujuan, dan metode penelitian, (2) memahami berbagai jenis penelitian pembelajaran bahasa dan sastra Indonesia: mencermati jenis penelitian dasar dan terapan, mencermati jenis penelitian kuantitatif dan kualitatif, mencermati jenis penelitian kualitatif interaktif dan noninteraktif, mencermati jenis penelitian tindakan, mencermati jenis penelitian pengembangan dalam pembelajaran bahasa dan sastra Indonesia; (3) memahami metode penelitian pembelajaran bahasa dan sastra Indonesia: mencermati sumber masalah, mencermati contoh rumusan masalah, mencermati contoh rumusan teori dan penyusunan kerangka teori, mencermati contoh penyusunan asumsi dan hipotesis, mencermati paparan data dan pembahasan hasil penelitian, dan mencermati contoh paparan temuan dan simpulan penelitian pembelajaran bahasa dan sastra Indonesia; (4) memahami prosedur penelitian pembelajaran bahasa dan sastra Indonesia: mencermati tahap persiapan penelitian, mencermati tahap pengumpulan data, mencermati tahap pengolahan data dan analisisnya, mencermati tahap validasi hasil analisis data, dan mencermati tahap penyusunan laporan penelitian pembelajaran bahasa dan sastra Indonesia; (5) memahami bahasa, tata tulis, dan format laporan penelitian pembelajaran bahasa dan sastra Indonesia: mencermati penggunaan bahasa Indonesia laporan penelitian, mencermati penerapan tata tulis laporan penelitian, mencermati pemilihan format laporan penelitian pembelajaran bahasa dan sastra Indonesia. Paparan topik-topik tersebut selalu diikuti dengan perlatihan sesuai dengan topik yang dibahas.

Sistematika penyajian materi. Isi materi bab I disajikan dengan sistematika: penyajian tujuan, kegiatan belajar dengan cara mencermati sajian isi materi tanpa perlatihan. Isi materi bab II-V disajikan dengan sistematika: penyajian tujuan, kegiatan belajar dengan cara mencermati sajian isi materi, dan perlatihan. Bab II berisi berlatih menganalisis judul dan permasalahan terkait dengan jenis penelitian dasar, terapan, kualitatif eksperimental dan noneksperimental, PTK, dan penelitian pengembangan dalam pembelajaran bahasa dan sastra Indonesia. Perlatihan pada bab III berisi mengidentifikasi sumber masalah; merumuskan masalah; mengidentifikasi teori dan menyusun kerangka pikir yang relevan; mengidentifikasi hipotesis; mengembangkan hasil identifikasi variabel, indikator, dan hipotesis; menganalisis kesesuaian teknik pembahasan dengan alur pikir penelitian; mengelaborasi dan merangkum hasil penelitian; dan menganalisis kesesuaian masalah dan paparan temuan; menganalisis kesesuaian temuan dan simpulan penelitian. Bab IV berisi perlatihan pemahaman teori prosedur penelitian dan aplikasinya dalam pembelajaran bahasa dan sastra Indonesia. Bab V berisi perlatihan menulis laporan penelitian dengan menerapkan aturan penulisan dan bahasa serta format yang tepat (PPKI UM,2016)

Bahan ajar yang baik haruslah memenuhi kriteria kelayakan (1) isi, (2) penyajian, (3) bahasa, dan (4) kegrafikaan (BSNP, 2006 ). Demikian juga dengan kelayakan bahan ajar Dasar-Dasar Penelitian Pembelajaran Bahasa dan Sastra Indonesia (PPBSI) ditinjau dari aspek (1) keterbacaan isi/materi, (2) keruntutan penyajian, dan (3) kemenarikan tampilan. Yang dinilai dari aspek keterbacaan isi/ materi mencakup kemudahan muatan informasi tentang (a) jenis penelitian, (b) metode penelitian, (c) prosedur penelitian, (d) penyusunan laporan hasil penelitian. Bahan ajar ini divalidasi oleh 4 validator selaku pengampu matakuliah penelitian. Hasilnya dikemukakan berikut ini. 


\section{Keterbacaan isi/materi}

Sebelum direvisi. Rancangan bahan ajar Dasar-Dasar Penelitian Pembelajaran Bahasa dan Sastra Indonesia ini berorientasi pada konsep. Hal itu tampak dalam daftar isi buku ajar yang masih bersifat pengetahuan. Saran dari validator agar materi bahan ajar ditekankan pada prosedur. Hal dimaksud dimunculkan dalam banyaknya aktivititas dalam kegiatan belajar.

Ruang lingkup bahan ajar Dasar-Dasar Penelitian ini meliputi (a) jenis penelitian, (b) metode penelitian, (c) prosedur penelitian, dan (d) penyusunan laporan hasil penelitian. Di dalam topik jenis penelitian dimunculkan jenis penelitian (i) fundamental dan terapan, (ii) kualitatif dan kuantitatif, (iii) tindakan, dan (iv) pengembangan. Topik metode penelitian pembelajaran bahasa dan sastra meliputi kegiatan mencari dan menemukan (i) sumber masalah penelitian dan pembelajaran bahasa dan sastra Indonesia (PPBSI), (ii) masalah penelitian PBSI, (iii) kedudukan dan peran teori dalam penelitian kuantitatif, dan (iv) kedudukan dan peran teori dalam penelitian kulitatif.

Bab tentangprosedur penelitian pembelajaran bahasa dan sastra Indonesia mancakup kegiatan melakukan (i) persiapan penelitian, (b) pengumpulan data, (c) pengolahan data, (d) penyajian data penelitian (kualitatif dan kuantitatif), dan (e) pemvalidasian data hasil penelitian. Terdapat tiga subaspek untuk penyusunan laporan hasil penelitian, yakni (i) organisasi/sistematika laporan hasil penelitian, (ii) penggunaan Bahasa Indonesia Keilmuan (BIK), serta (iii) penerapan ejaan dan tanda baca.

Instrumen validasi keterbacaan materi bahan ajar terdiri atas dua komponen, yakni (a) pengantar dan (b) petunjuk. Dalam bagian pengantar diberikan informasi umum tentang kriteria atau persyaratan bahan ajar yang layak. Isinya meliputi (i) aspek yang dinilai, (ii) hasil telaah/ skor-terdiri atas skala 5-, dan (iii) catatan per aspek. Di akhir instrumen diberikan kolom komentar umum untuk perlayakan instrumen oleh validator.

Hasilnya dipaparkan berikut ini. Validator satu, aspek yang divalidasi untuk jenis penelitian memperoleh skor 16 dari 20 SMI (Skor Maksimal Ideal). Catatan yang diberikan oleh validator adalah "...akan lebih jelas informasinya jika di dalam butir-butir." Aspek metode penelitian yang divalidasi meliputi kemudahan muatan informasi tentang (i) sumber masalah penelitian, (ii) cara menemukan masalah dalam penelitian, (iii) cara mengenali kedudukan dan peran teori dalam penelitian kuantitatif, (iv) cara mengenali kedudukan dan peran teori dalam penelitin kualitatif. Hasilnya diperoleh skor 12 dari skor maksimal ideal 20. Catatan yang diberikan oleh validator satu adalah "informasi tentang metode penelitian akan lebih layak apabila (aspek metode penelitian dipetakan)."

Aspek prosedur penelitian yang divalidasi meliputi kemudahan muatan informasi tentang cara (i) melakukan persiapan penelitian, (ii) mengumpulkan data penelitian, (iii) menganalisis data penelitian, (iv) menyajikan data penelitian, (v) membahas data penelitian, dan (v) melakukan validasi data hasil penelitian. Hasilnya, diperoleh skor 24 dari skor 30. Validator satu menyarankan agar dalam topik prosedur penelitian dilengkapi dengan contoh-contoh .

Topik Penyusunan laporan hasil penelitian mencakup 3 aspek penilaian, yakni (i) kesesuaian organisasi penulisan laporan, (ii) kemudahan muatan informasi tentang cara menggunakan Bahasa Indonesia Keilmuan (BIK), dan (iii) kemudahan muatan informasi tentang cara menerapkan ejaan dan tanda baca. Validator satu memberikan skor 15 dari skor maksimal ideal 15. Validator tidak memberikan komentar. Secara umum validator memberikan komentar bahwa buku ajar yang berjudul Dasar-DasarPenelitian PBSI layak digunakan dari sisi keterbacaannya. 


\section{Keruntutan Penyajian}

Penyajian topik-topik penelitian dalam bahan ajar diurutkan sebagai berikut: (1) bab I Pendahuluan berisi uraian tentang latar belakang keterlambatan penulisan skripsi mahasiswa, tujuan penelitian, dan metode penelitian menyusun buku ajar ini; (2) bab II menguraikan berbagai jenis penelitian pembelajaran bahasa dan sastra Indonesia dengan urutan mencermati tujuan, kegiatan belajar, dan latihan; (3) bab III menguraikan metode penelitian pembelajaran bahasa dan sastra Indonesia dengan urutan mencermati tujuan, kegiatan belajar, dan latihan; (4) bab IV menguraikan prosedur penelitian pembelajaran bahasa dan sastra Indonesia dengan urutan mencermati tujuan, kegiatan belajar, dan latihan; dan bab V menguraikan penggunaan bahasa keilmuan, tatatulis, dan format laporan dengan urutan mencermati tujuan, kegiatan belajar, dan latihan. Buku Ajar diakhiri dengan daftar rujukan, glosarium, dan indeks.

Hasil validasi menunjukkan bahwa rerata skor capaian nilai yang diberikan validator adalah 67-78 dari capaian skor ideal 85-100. Saran masukan dari validator adalah agar uraian di bab II-III diperbanyak dengan peta konsep dan bagan atau alur penelitian. Rerata skor capaian nilai tergolong cukup layak dari sisi keruntutan penyajian.

\section{Kemenarikan Tampilan}

Format buku ajar ini adalah $15,5 \times 23$ cm dengan tebal 168 halaman. Halaman sampul berisi nama penulis judul dan anak judul dan label penerbit. Ukuran huruf besar dan penggunan huruf kapital ada pada judul. Halaman sebelum pengantar ditampilkan data publikasi yang berisi: judul dan subjudul buku, inisial penulis, nama layoter, identitas penerbit, cetakan ke-, ukuran buku dan jumlah halaman, ISBN, dan UU hak cipta dalam jenis huruf arial ukuran 14. Sebelum Bab I didahului kata pengantar dan daftar isi.
Penggunaan angka Arab dan huruf besar kecil ada di setiap bab. Pada setiap bab dilengkapi dengan skema atau bagan. Buku ini dilengkapi dengan glosarium, indeks, dan catatan belakang pada halaman akhir buku.

Hasil validasi menunjukkan bahwa rerata skor capaian nilai yang diberikan validator adalah 73-78 dari capaian skor ideal 85-100. Saran masukan dari validator adalah di halaman sampul agar judul dan subjudul ditulis paling atas, di bawanya inisial penulis, warna sampul agar dipilih yang cerah. Huruf kapital agar digunakan dalam bab-bab, bagan dan skema agar bervariasi. Warna pada halaman belakang agar dipilih yang cerah. Rerata skor capaian nilai tergolong cukup layak dari sisi kemenarikan tampilan.

\section{Prototipe Sarana Monitoring Proses Penulisan Skripsi}

Prototipe sarana monitoring yang dikembangkan mencakup empat hal, yaitu (1) Sarana Monitoring Penyusunan Proposal Penelitian, (2) Sarana Monitoring Seminar Proposal Penelitian, (3) Sarana Monitoring Pelaksanaan Penelitian, dan (4) Sarmon Penulisan Laporan Penelitian. Keempat hal tersebut diuraikan sebagai berikut.

Pertama, sarana monitoring penyusunan proposal penelitian berisi: (1) identitas atau nama mahasiswa, angkatan/semester, dan judul proposal;(2) aspek yang dimonitor mencakup 6 aktivitas, yakni mengonsultasikan: (i) topik dan judul penelitian, (ii) fokus/masalah penelitian, (iii) kajian pustaka, (iv) pendekatan penelitian, (v) rancangan/desain penelitian, dan (vi) daftar rujukan; (3) telaah dan skoring kegiatan konsultasi mahasiswa,(4) catatan yang berisi komentar oleh pembimbing skripsi,(5) nilai aktivitas mahasiswa berdasarkan rumus penilaian yang disediakan.

Kedua, instrumen monitoring pelaksanaan seminar proposal penelitian berisi: 
identitas mahasiswa dan judul proposal, aspek yang dimonitor, catatan atau saran pembimbing I dan II serta kualifikasi hasil seminar. Aspek kegiatan mahasiswa yang dimonitor adalah mempresentasikan: (i) topik dan judul penelitian, (ii) latar belakang masalah dan tujuan penelitian, kajian pustaka, pendekatan penelitian, rancangan penelitian, dan daftar rujukan proposal.

Ketiga, ada 6 aktivitas mahasiswa yang harus dimonitor dalam pelaksanaan penelitian, yakni mengonsultasikan (i) cara mengumpulkan data, (ii) cara mengolah data, (iii) cara memvalidasi hasil mengolah data, (iv) cara menyimpulkan hasil penelitian, (v) cara merekomendasikan hasil penelitian, dan (vi) cara menuliskan daftar rujukan.

Keempat, instrumen penulisan laporan penelitian berisi 5 aktitivitas mahasiswa yang harus dimonitor, yakni mengonsultasikan: (i) bab pendahuluan, (ii) bab kajian pustaka, (iii) bab metodologi, (iv) bab penyajian hasil, dan (vi) bab penutup.

Sebelum direvisi pada pengantar instrumen belum jelas apa saja cakupan proses penulisan skripsi. Matriks isian monitoring proses penulisan skripsi dengan memberikan tanda contreng untuk kolom sudah atau belum. Tidak ada petunjuk yang jelas apa artinya sudah dan belum, serta catatan yang harus diberikan oleh pembimbing pada tempat yang disediakan.

Berdasarkan hasil uji kelayakan disarankan untuk dilakukan perubahan aspek yang dimonitor dan kualifikasi proses pembimbingan yang dilakukan oleh mahasiswa. Setelah direvisi, sarmon proses pembimbingan penulisan skripsi adalah sarana monitoring untuk (1) penyusunan proposal, (2) seminar proposal, (3) pelaksanaan penelitian, (4) seminar hasil penelitian, dan (5) penulisan draf laporan (skripsi). Kualifikasi pembimbingan adalah ya dengar skor 2, kurang skor 1 dan tidak skor 0 . Perolehan skor maksimal ideal adalah 56 dengan makna sangat layak.

Sebelum direvisi, jumlah aspek yang dinilai 18 butir, setelah direvisi berubah menjadi 28 butir. Itu artinya proses bahwa pemantauan proses penulisan skripsi perlu keketatan dan kedisiplinan tinggi. Hasil validasi kelayakan 'Sarmon Penulisan Skripsi' disajikan pada Tabel 1.

\section{Prototipe Sarana Monitoring (Sarmon) Produk Penulisan Skripsi \\ Sarana Monitoring Panduan Penilai- an Kelayakan Naskah Skripsi}

Ada 6 aspek yang dinilai untuk naskah yang dihasilkan, yakni (i) judul skripsi, (ii) pendahuluan, (iii) kajian pustaka/ teori, (iv) metode penelitian, (v) hasil

Tabel 1. Kelayakan Sarana Monitoring Penulisan Skripsi

\begin{tabular}{|c|c|c|c|c|c|}
\hline $\begin{array}{c}\text { Aspek } \\
\text { yang } \\
\text { dinilai } \\
\end{array}$ & $\begin{array}{c}\text { Proses } \\
\text { penulisan } \\
\text { skripsi }\end{array}$ & $\begin{array}{c}\text { Skor } \\
\text { capaian- } \\
\text { nilai rerata }\end{array}$ & $\begin{array}{c}\text { Skor } \\
\text { maksimal- } \\
\text { nilai }\end{array}$ & $\begin{array}{c}\text { Kategori atau } \\
\text { Kualifikasi }\end{array}$ & $\begin{array}{l}\text { Saran- } \\
\text { masukan }\end{array}$ \\
\hline 1 & $\begin{array}{l}\text { Penyusunan } \\
\text { proposal }\end{array}$ & 12 & 15 & layak & \\
\hline 2 & $\begin{array}{l}\text { Seminar } \\
\text { proposal }\end{array}$ & 16 & 20 & layak & \\
\hline 3 & $\begin{array}{l}\text { Pelaksanaan } \\
\text { penelitian }\end{array}$ & 17 & 20 & layak & \\
\hline & Seminar hasil & 17 & 20 & layak & \\
\hline 4. & $\begin{array}{l}\text { Penyusunan } \\
\text { laporan }\end{array}$ & 17 & 20 & layak & \\
\hline
\end{tabular}


penelitian, (vi) penutup, (vii) bahasa dan teknis mekanis. Berdasarkan 6 aspek itu ditelaah dan diberi skor 1-5, dan catatan jika diperlukan, dan kriteria penilaian.

Sebelum direvisi panduan monitoring kelayakan naskah bersifat umum. Monitoring kelayakan naskah dihubungkan dengan enam bab dalam laporan penelitian, yakni pendahuluan, kajian pustaka, metode penelitian, paparan data, pembahasan, dan penutup. Setelah direvisi panduan monitoring kelayakan naskah deperinci mulai perumusan judul sampai dengan penggunaan bahasa dan teknis mekanis. Validasi instrumen kelayakan naskah disajikan pada Tabel 2.

\section{Sarana Monitoring Panduan Penilaian Ujian atau Sidang Skripsi}

Panduan penilaian ujian skripsi didahului oleh pengantar dan petunjuk penilaian. Panduan penilaian berisi: aspek yang dinilai, catatan, dan kriteria penilaian. Aspek yang dinilai meliputi kualitas sikap dan kualitas unjuk kerja. Kualitas sikap berisi 5 butir, yakni (i) ketelitian/kecermatan, (ii) kejujuran, (iii) kesantunan, (iv) kedisiplinan, dan (v) ketanggungjawaban. Kualitas unjuk kerja berisi 5 butir juga, yakni (i) kemampuan meresponsi pertanyaan, saran,masukan, (ii) kemampuan mengeksplanasi hasil penelitian, (iii) kemampuan memberikan bukti dan argumentasi, (iv) kemampuan memertahankan opini, dn (v) kemam-

Tabel 2. Instrumen Validasi Draf Laporan (Naskah Skripsi)

\begin{tabular}{llllllll}
\hline No & ASPEK & 1 & 2 & 3 & 4 & 5 & Catatan, masukan \\
\hline 1 & Ketepatan aspek yang dimonitor & & & & & & \\
2 & Kelengkapan aspek yang dimonitor & & & & & \\
3 & $\begin{array}{l}\text { Kepraktisan penggunaan panduan } \\
\text { monitoring }\end{array}$ & & & & & \\
4 & $\begin{array}{l}\text { Kefungsionalan penggunaan } \\
\text { panduan monitoring }\end{array}$ & & & & & \\
\hline
\end{tabular}

Tabel 3. Validasi Kelayakan Sarana Monitoring Kelayakan Naskah

\begin{tabular}{|c|c|c|c|c|c|}
\hline Aspek yang dinilai & $\begin{array}{l}\text { Komponen } \\
\text { Naskah }\end{array}$ & $\begin{array}{c}\text { Skor } \\
\text { capaian- } \\
\text { nilai } \\
\text { rerata }\end{array}$ & $\begin{array}{c}\text { Skor } \\
\text { maksimal- } \\
\text { nilai }\end{array}$ & $\begin{array}{c}\text { Kategori } \\
\text { atau } \\
\text { Kualifikasi }\end{array}$ & $\begin{array}{l}\text { Saran- } \\
\text { masukan }\end{array}$ \\
\hline & Judul & 8 & 10 & layak & \\
\hline 1. Ketepatan aspek & Pendahuluan & 12 & 15 & layak & \\
\hline $\begin{array}{l}\text { 2. Kelengkapan } \\
\text { aspek }\end{array}$ & $\begin{array}{l}\text { Kajian } \\
\text { Pustaka }\end{array}$ & 9 & 10 & layak & \\
\hline $\begin{array}{l}\text { 3. Kepraktisan } \\
\text { penggunan }\end{array}$ & $\begin{array}{l}\text { Metode } \\
\text { Penelitian }\end{array}$ & 8 & 10 & layak & \\
\hline \multirow{4}{*}{$\begin{array}{l}\text { 4. Kefungsionalan } \\
\text { penggunaan } \\
\text { panduan }\end{array}$} & Hasil & 7 & 10 & layak & \\
\hline & Penelitian & & & & \\
\hline & Penutup & 10 & 10 & $\begin{array}{c}\text { Sangat } \\
\text { layak }\end{array}$ & \\
\hline & $\begin{array}{l}\text { Bahasa dan } \\
\text { Teknis } \\
\text { Mekanis }\end{array}$ & 21 & 25 & layak & \\
\hline
\end{tabular}


Tabel 4. Instrumen Validasi Kelayakan Sarana Monitoring Ujian Naskah Skripsi

\begin{tabular}{llllllll}
\hline NO & ASPEK & 1 & 2 & 3 & 4 & 5 & Catatan, masukan \\
\hline 1 & Ketepatan aspek yang dinilai & & & & & & \\
2 & Kelengkapan aspek yang dinilai & & & & & & \\
3 & $\begin{array}{l}\text { Kepraktisan penggunan panduan } \\
\text { penilaian }\end{array}$ & & & & & & \\
4 & $\begin{array}{l}\text { Kefungsionalan penggunaan panduan } \\
\text { penilaian }\end{array}$ & & & & & \\
\hline
\end{tabular}

Tabel 5. Hasil Validasi Kelayakan Sarana Monitoring Ujian/Sidang Skripsi

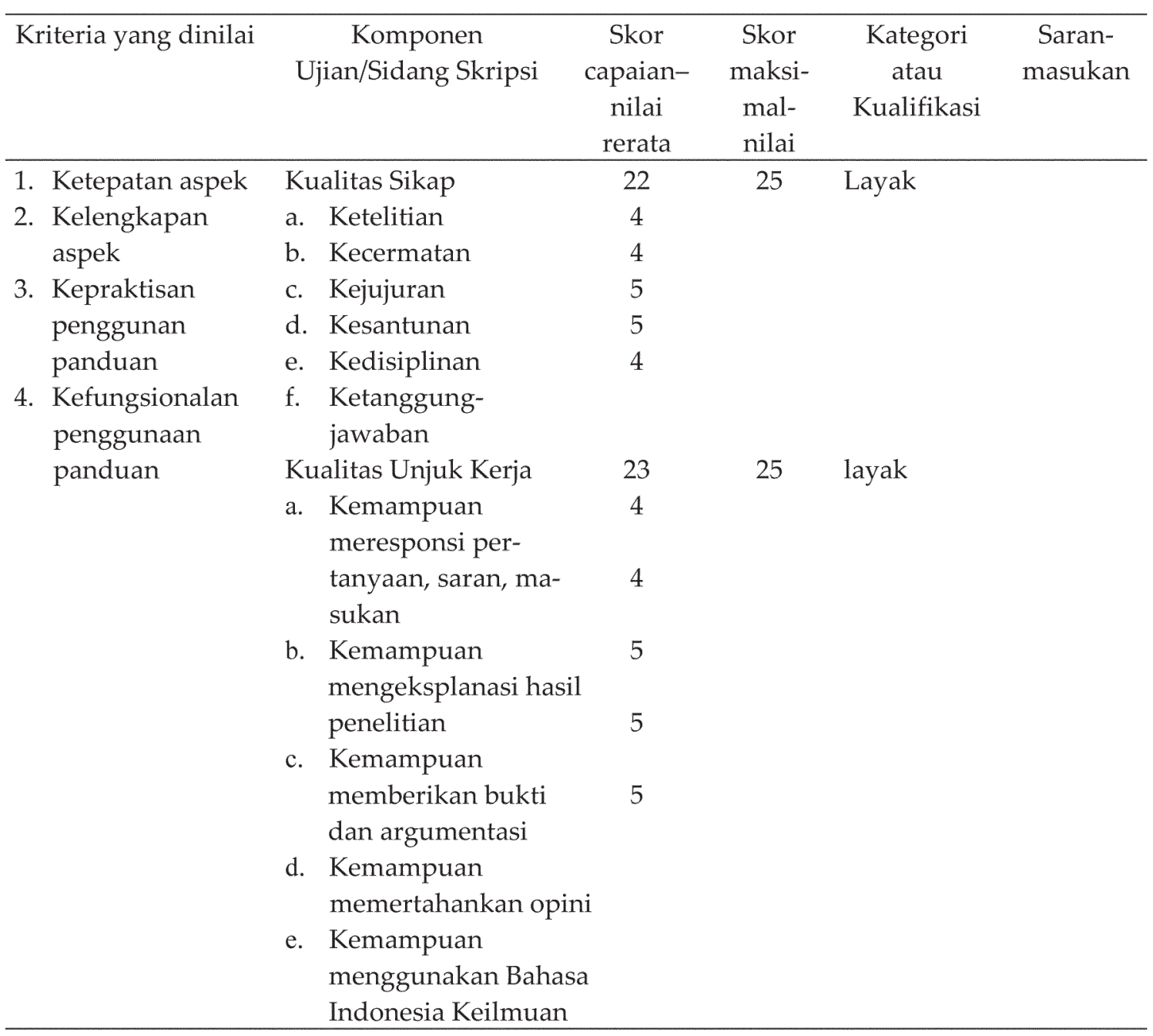

puan menggunakan Bahasa Indonesia Keilmuan (BIK).

Catatan berisi masukan, komentar, dan pendapat dari validator berdasarkan telaah aspek dan skor. Kriteria penilaian dilakukan dengan menggunakan rumus yang ditentukan. Hasilnya pemberian kualifiasi capaian dalam skala tidak baik sampai sangat baik.

Sebelum direvisi panduan monitoring ujian skripsi terdiri atas unsur (a)pemaparan hasil penelitian, (b) kebenaran gagasan atau logika berpikir, (c) bahasa yang digunakan saat presentasi, (d) keperca- 
yaan diri saat presentasi. Setelah direvisi panduan sarmon ujian skripsi terdiri atas dua aspek, yakni aspek kualitas sikap dan unjuk kerja dengan skor maksimal maksimal 50.

\section{SIMPULAN}

Perangkat pembelajaran untuk mempercepat penyelesaian skripsi mahasiswa diwujudkan dalam pertama, panduan proses penulisan skripsi berupa (a) panduan penyusunan proposal, (b) panduan seminar proposal, (c) panduan pelaksanaan penelitian, dan (d) panduan seminar hasil penelitian. Kedua, panduan produk penulisan skripsi berupa (a) panduan penilaian kualitas draf/naskah skripsi dan (b) panduan ujian skripsi. Kedua kelompok panduan tersebut berfungsi sebagai sarana monitoring (sarmon) untuk pemercepatan penulisan skripsi mahasiswa. Hasil validasi menunjukkan bahwa panduan proses penulisan dan produk penulisan skripsi tersebut layak untuk digunakan.

Dalam realisasinya, perangkat sarmon proses dan produk penulisan skripsi dipadukan dengan tersusunnya bahan ajar Dasar-Dasar PenelitianPembelajaran Bahasa dan Sastra Indonesia. Hasil validasi menunjukkan bahwa bahan ajar tersebut telah memenuhi standar kelayakan ditelaah dari keterbacaan isi, keruntutan penyajian, dan kemenarikan tampilan. Pada tahun ketiga perangkat Sarmon monitoring proses dan produk penulisan skripsi serta bahan ajar akan diuji lapangan. Uji lapangan dilakukan dengan tujuan untuk membuktikan keefektifan perangkat pembelajaran berupa Sarmon proses dan produk penulisan skripsi dan bahan ajar Dasar-Dasar Penelitian tersebut untuk mempercepat penyelesaian skripsi mahasiswa.

\section{UCAPAN TERIMA KASIH}

Melalui forum ini peneliti menyampaikan terima kasih kepada beberapa pihak yang memfasilitasi terlaksananya penelitian Hibah Bersaingini. Pertama, ucapan terima kasih disampaikan kepada Direktur DP2M Dikti yang mendanai penelitian ini sampai tahun kedua dari tiga tahun yang direncanakan. Kedua, ucapan terima kasih disampaikan kepada Kepala Lembaga Penelitian dan Pengabdian kepada Masyarakat (LP2M) Universitas Negeri Malang beserta stafnya yang telah memberikan banyak kemudahan untuk kelancaran penelitian ini. Ketiga, ucapan terima kasih dan penghargaan yang tulus ditujukan kepada (a) tendik LP2M, (b) tendik fakultas sastra yang memperlancar urusan administrasi penelitian ini. Demikian juga kolega dosen Jurusan Sastra Indonesia yang telah memberikan validasi pada perangkat pembelajaran ini. Harapan peneliti mudah-mudahan hasil penelitian ini memberikan makna dan manfaat untuk kelancaran studi mahasiswa. Aamiin.

\section{DAFTAR PUSTAKA}

Anderson, L., \& Krathwohl, D. 2001. A Taxonomy for Learning, Teaching and Assessing: A Revision of Bloom's Taxonomy of Educational Objectives. NewYork: Longman.

Ardianto. 2015. “Struktur Argumen dalam Wacana Karya Tulis Ilmiah Mahasiswa". Dalam LITERA, Volume 14, Nomor 1, April 2015, hlm. 1-10.

Badan Standar Nasional Pendidikan (BSNP). 2006. Instrumen Penilaian Tahap I Buku Teks Pelajaran Pendidikan Dasar dan Menengah. Jakarta: BSNP.

Borg, W.K. \& Gall, M.D. 2003. Education Research. White Plains: Longman Inc.

Ditbelmawa Dikti. 2014. Buku Kurikulum Pendidikan Tinggi. Jakarta: Ditbelmawa Dikti.

Fakultas Sastra Universitas Negeri Malang. 2014. Data Yudisium Mahasiswa Fakultas Sastra. Malang: UM.

Hartato, Ujang. 2016. “Faktor-Faktor yang Mempengaruhi Penyelesaian Skripsi 
Mahasiswa Program Studi Pendidikan Akuntansi Fakultas Ekonomi Universitas Negeri Yogyakarta Angkatan 2011". Yogyakarta: Skripsi, tidak diterbitkan.

Menteri Pendidikan dan Kebudayaan Republik Indonesia. 2013. Peraturan Menteri Pendidikan dan Kebudayaan Republik Indonesia Nomor 73 Tahun 2013tentang Penerapan Kerangka Kualifikasi Nasional Indonesia Bidang. Jakarta: Depdikbud.

Miles, M. B dan A. M. Huberman. 1992. Qualitative Data Analysis. Sage Publications,Inc.

Pendidikan Tinggi. Jakarta, Indonesia: Kementerian Pendidikan dan Kebudayaan Republik Indonesia.

Setiadi, Riswanda. 2016. "Kemampuan Menulis Akademik Guru Mata Pelajaran Non-Bahasa di Jawa Barat". Dalam
LITERA, Volume 15, Nomor 1, April 2016, hlm. 63-75.

Soehardjo. 2005. "Panduan Menulis dan Mempresentasikan Karya Ilmiah: Tesis, Tugas Akhir, dan Makalah'. http://ebookbrowsee.net. Diakses 28 Agustus 2014.

Universitas Negeri Malang. 2011. Katalog Jurusan Sastra Indonesia. Malang: Universitas Negeri Malang.

Universitas Negeri Malang. 2012. Statuta Universitas Negeri Malang. Malang: Universitas Negeri Malang.

Universitas Negeri Malang. 2015. Rencana Strategis Bisnis Universitas Negeri Malang 2015-2019. Malang: Universitas Negeri Malang.

Universitas Negeri Malang. 2016. Pedoman Penulisan Karya Ilmiah. Malang: Universitas Negeri Malang. 